International Journal of Management and Sustainability

2021 Vol. 10, No. 4, pp. 114-122.

$\operatorname{ISSN}(e):$ 2306-0662

$\operatorname{ISSN}(p): 2306-9856$

DOI: 10.18488/journal.11.2021.104.114.122

(C) 2021 Conscientia Beam. All Rights Reserved.

check for
updates

\title{
CUSTOMER RELATIONSHIP MANAGEMENT (CRM) IN THE PUBLIC AND PRIVATE SECTOR BANKS IN BIHAR: A COMPARATIVE STUDY
}

Indrajit Kumar
(i) Mihir Kumar
Shome ${ }^{2+}$
(i) Jainendra Kumar
Verma $^{3}$
(iD) Arun Kumar

Arun Kumar

\author{
'Assistant Professor, Department of Management Studies, MVJ College of \\ Engineering (Autonomous), Bangalore, India. \\ Email: kind30indra@gmail.com Tel: : 8416006965 \\ ${ }^{\circ}$ Professor, Department of Management and Humanities National Institute \\ of Technology, Arunachal Pradesh, India. \\ Email:prof.mihir.shome@gmail.com Tel:9436290384 \\ ${ }^{3}$ Assistant Professor, Department of Economic Studies, Central University of \\ Punjab, Bathinda, Punjab, India. \\ Email:jainendrakumarverma@yahoo.co.in Tel: 9919494419 \\ ${ }^{*}$ Assistant Professor, Department of Management Sciences, Mahatma Gandhi \\ Central University, Motihari, Bihar, India. \\ Email:arun.vaisali@gmail.com Tel: 8340647802
}

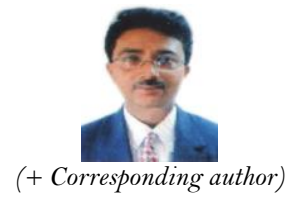

(+ Corresponding author)
Article History

Received: 5 August 2021 Revised: 8 October 2021 Accepted: 19 November 2021 Published: 16 December 2021

\section{Keywords}

Banking sector

Customer relationship

management (CRM)

Descriptive

Inferential statistics

Perceptions.

\begin{abstract}
Customer relationship management (CRM) plays a crucial role in any organization because success or failure depends on a company's relationship with its customers. The objective of this study is to see how CRM can play an important role in the public and private sector banks in Bihar, India. The sample for the study consists of 250 bank managers from both public and private sector banks in Bihar. A CRM questionnaire developed by the researchers was used to measure CRM in the banking sector. Data were analyzed using SPSS software. Inferential statistics including t-test and analysis of variance (ANOVA) were used to analyze the data. The t-test results show that both the public and private sector banks differ significantly in the variables of customer contact by phone/e-mail, customer care, and innovation and quality. The ANOVA results showed that the four groups (public sector males, public sector females, private sector males, and private sector females) differed significantly in the eight variables (commitment; citizenship behavior; customer contact by phone/e-mail; planning; improved retention \& better targeting of new customers; top management support; innovation and quality; and technological readiness.
\end{abstract}

Contribution/Originality: This study is one of the very few studies which has investigated the implementation of CRM in both public and private sector banks in Bihar, India, and will help researchers, academicians, bank managers, and policymakers to understand the importance of CRM in the banking sector.

\section{INTRODUCTION}

One of the most crucial aspects of the business throughout the history of business has been customer relationships. Customer relationship management (CRM) plays a crucial role in any organization because success or failure depends on the relationship with the customers. CRM is the most important technique for building relationships and attracting customers in the banking sector. It focuses on understanding the basic needs, wants, and demands of customers as individuals instead of as part of a group. The main focus of CRM is to manage the relationships between banks and its customers. CRM concentrates on continuously delivering a good quality of service to customers. In today's competitive world we have seen that banks and other companies are realizing the 
significance of CRM techniques and their prospects which have helped them to attract and acquire new customers and can maximize profit. According to Peppers \& Rogers (2004), banks are customer-based services where the customer is the primary focus. Therefore, research is mandatory in such a sector to understand the customer's basic needs, wants, desires, attitudes, and views to build long-term relationships. CRM includes operational, socioeconomic, financial, marketing, cultural, and other activities, which help us to progress, maintain, establish and sustain a better relationship with the targeted customers, and it also helps in maintaining the most effective relationship between customers and banks which depends on the understanding of the different needs and wants of customers at different stages. The main objective of this study is to successfully analyze all the data about the customers which also helps banks to measure a customer's current and potential profitability, satisfaction, and loyalty. When banks respond to customers' needs, this makes the customers feel valued rather than just one of a large number of customers. Customer relationship management is a broad professional technique used to determine the most profitable customers and prospects, so the banks can then commit time and attention to expanding longterm relationships with those customers through personalized marketing, reprising, discretionary decision making, and customized services, which they can easily deliver through various sales and communication channels (Zeithmal \& Bitner, 2003).

\section{REVIEW OF LITERATURE}

According to Berry (1983), CRM attracts, builds, maintains and enhances good relationships with employees as well as customers in different service organizations. After spending a few years on the study, Berry defined the evolution of relationship marketing, which has seen "relationship marketing" change to "customer relationship management". Parasuraman, Zeithaml, \& Berry (1985) state that high-quality service gives credibility to the field sales force and advertisements, stimulates favorable word-of-mouth communications that enhance customers' perception of a company's value, and it also boosts morale and loyalty of employees and customers alike. Dwyer, Schurr, \& Oh (1987) suggested that banks should consider the customer relationship lifecycle for improving the nature of work in different organizations. Hallowell (1996) found that in public sector banks, customers' level of satisfaction is higher compared to private sector banks. Puccinelli (1999) observed that, nowadays, the financial services business is entering a new era where personal attention is decreasing because institutions are using new CRM technology to replace human contact in many areas. Brown (2000) has discussed that CRM is a process of acquiring new customers, retaining existing customers and, at the same time, understanding, anticipating, and managing the needs of banks' current and potential customers. Swift (2001) stated that companies can gain so many benefits through CRM implementation. The benefits that have been commonly found include recruiting customers at a lower cost, maintaining a steady volume of business without the need to acquire many new customers, reducing the cost of sales, achieving higher customer profitability, increasing customer retention and loyalty, and evaluating customers' profitability.

Sherif (2002) found that technical growth of new CRM techniques in the last few years have highly affected the banking sector as well as other organizations. Panda (2003) said that CRM is a closed-loop system which fetches its input from customers' actions. Sachdev \& Verma (2004) stated that, in today's competitive world, customers have to choose among various service providers by making a trade-off between relationships and economies, trust and products, or service and efficiency.

Wang, Lo, Chi, \& Yang (2004) developed a framework for customer value and CRM performance based on the identification of the key dimensions of customer value, such as functional value, social value, emotional value, and perceived sacrifices. Picton \& Broderic (2005) posited that CRM emphasizes the importance of the relationships developed between an organization and its customers. It also involves strategic and tactical management tasks to achieve positive communications and long-term customer relationships. Kotler \& Keller (2006) stated that the main objective of CRM is to recognize and treat each and every customer as an individual. Customer relationship 
management enables organizations to provide a good quality of real-time customer services through the effective use of individual account information. Ray (2007) said that it is also important in research to understand that if customers bring more profits to the bank, it becomes almost imperative for the banks to provide an excellent quality of services and products to those customers, otherwise they may switch to other banks.

Rootman, Tait, \& Bosch (2008) investigated the variables that influence the effectiveness of CRM strategies in banks, including attitude, knowledgeability, and two-way communication related to bank employees in the banking industry. Bansal \& Sharma (2008) have given a clear vision of CRM along with suitable strategies that, if applied in banks, would be beneficial in maintaining a good quality of service and customer satisfaction and retention, which ultimately leads to the growth and profitability of the organization. Pahuja \& Verma (2008) said that CRM should include a deep understanding of customer attitudes, expectations, and behaviors through a well-organized and maintained customer database and innovative customer strategies. The main aim of CRM is to ensure customer satisfaction at every level. Mylonakis (2009) described CRM as a process of maintaining a good and long-term relationship with customers and bank employees, and it also tries to win the hearts and trust of customers. Girdhar (2009) observed that by satisfying internal and external customers and building a good relationship with them, relationships with external customers can also be retained and satisfied with the help of a new CRM technique.

Kumar, Ashok, \& Rajesh (2009) stated that if any bank wants to grow in its field of operation, or wants to maximize its profitability, it must face the challenges which may affect its relationships with its customers. Hussain, Hussain, Hussain, \& Sajid (2009) emphasized that CRM is a process to create a superior customer experience, which helps to manage customer relationships by creating a good understanding of their needs and delivering quality products and services based on added value for target customers. Dwyer et al. (1987) found that customer relationship management is an infrastructure that allows an increase in customer value and the correct means by which to motivate valuable customers to remain loyal. Tamilarasan (2011) mentioned that CRM becomes more effective when customers are actively involved in CRM processes. If CRM practices are conceived and implemented properly then they will enable the organization to retain customers for a lifetime, get maximum value out of each customer and generate exemplary customer bonding. Another study found that CRM involves more than just gathering data and developing programs to identify the most profitable customers and then trying to manage the relationships by offering these customers more suitable products and services at more affordable prices.

Payne (2012) found that managing CRM is a difficult and continuous process, and it requires a response from organizations as the external environment rapidly changes, therefore, it is imperative that organizations view CRM from a broader and long-term perspective. Wali \& Opara (2013), in a study on the banking sector, found that CRM may be more important for the banking sector to focus more on managing the overall downward migration of customer spending than customer retention. Many customers simply change their buying behavior rather than it being a defect. An important objective of CRM implementation is improving customer retention. It is important to remember that the fundamental purpose of focusing CRM efforts on customer retention is to ensure that the organization maintains its relationships with value-adding customers. Adiele \& Opara (2014) explained that customer retention comes after customer identification. Retained customers are generally more profitable than newly acquired customers. Customer retention is the maintenance of continuous trading relationships with customers over a long period and is the mirror image of customer defection. The higher an organization's retention rate, the lower its level of defection will be. Rahimi \& Kozak (2017) observed that customer relationship management is the way to reduce costs and increase company performance and quality, which means profitability comes as a result of customer loyalty. In general, there are three core phases: customers' achievement, customers' enhancement, and customers' recovery. The achievement phase describes the initiation of a relationship between a customer and the bank manager. 


\section{STUDY OBJECTIVES}

1. To find out the significant differences between public and private sector bank managers regarding the variables of customer relationship management (CRM) in Bihar.

2. To find out the significant difference among the four groups of bank managers (public sector males, public sector females, private sector males, and private sector females) on the variables of customer relationship management $(\mathrm{CRM})$ in Bihar.

\section{HYPOTHESES OF THE STUDY}

Hypothesis 1:

(Ho): There is no significant difference between public and private sector bank managers for the variables of customer relationship management (CRM) in Bihar.

(H1): There is a significant difference between public and private sector bank managers for the variables of customer relationship management (CRM) in Bihar.

Hypothesis 2:

(Ho): There is no significant difference among the four groups of bank managers (public sector males, public sector females, private sector males, and private sector females) for the variables of customer relationship management (CRM) in Bihar.

(H1): There is a significant difference among the four groups of bank managers (public sector males, public sector females, private sector males, and private sector females) for the variables of customer relationship management (CRM) in Bihar.

\section{STUDY METHODS}

The present study was carried out on the public and private sector banks in Bihar. The importance of the study reveals that, nowadays, customers' need should be fulfilled with the help of new customer relationship management techniques, and customer relationship management (CRM) should be improved in the banking sector.

\subsection{Sample}

In this study, the purposive sampling method was used for data collection from a total of 250 bank managers, who were selected from the three districts of Bihar State, India, namely Nalanda, Patna, and Muzaffarpur. Among the 250 bank managers, 140 were selected from public sector banks, such as the State Bank of India, UCO Bank, United Bank of India, Bank of India, and Punjab National Bank. Similarly, 110 bank managers were selected from private banks, such as ICICI Bank, HDFC Bank, Yes Bank, Axis Bank, IndusInd Bank, and Kotak Mahindra Bank. Out of the 140 public sector bank managers, 104 were male and 36 were female, and out of the 110 private sector bank managers, 70 were male and 40 were female. The age range of the respondents is from 26 to 52 years.

\subsection{Data Collection}

Each researcher has used different variables and different terms in relation to measuring CRM, but none of these were completely relevant to banking. Therefore, it was decided that a questionnaire would be drawn up to cater to the uniqueness of this sector (see Appendix A). A five-point Likert scale was used for the responses $(1=$ Strongly disagree, $2=$ Disagree, $3=$ Neither agree nor disagree, $4=$ Agree, $5=$ Strongly agree). A high score in the respective dimension shows customers' high satisfaction, and vice versa. Adequate internal consistencies range from .69 to .86 , and reliabilities range from 0.71 to 0.93 on the scale.

\subsection{Procedure}

The questionnaire was administered and explained to the 250 bank managers, and they were asked to read the instructions given at the beginning. Any difficulty in understanding the instructions or the method of answering the questions was clarified. The respondents were informed that this study would be used for research purposes 
only and that their responses would be kept confidential. They answered the CRM questions on the spot so that their immediate reaction was recorded.

\subsection{Data Analysis}

Data were analyzed using SPSS (Statistical Package for the Social Sciences) software. Descriptive statistics include the mean and standard deviation, and inferential statistics include the t-test and analysis of variance (ANOVA).

Table 1. The significance of the mean difference between public vs private sector bank managers on customer relationship management (CRM) in Bihar.

\begin{tabular}{|c|c|c|c|c|c|c|c|c|}
\hline \multirow[t]{2}{*}{ Name of the Variable } & \multicolumn{3}{|c|}{ Public Bank Managers } & \multicolumn{3}{|c|}{ Private Bank Managers } & \multirow[t]{2}{*}{ T-value } & \multirow{2}{*}{$\begin{array}{c}\text { Level of } \\
\text { Significance }\end{array}$} \\
\hline & Mean & SD & $\mathbf{N}$ & Mean & SD & $\mathbf{N}$ & & \\
\hline Adaptation & 3.69 & 0.87 & 140 & 3.56 & 0.89 & 110 & 1.17 & $\mathrm{NS}$ \\
\hline Trust & 3.28 & 0.98 & 140 & 3.17 & 0.98 & 110 & 0.89 & $\mathrm{NS}$ \\
\hline Commitment & 4.30 & 0.69 & 140 & 4.41 & 0.52 & 110 & 1.40 & $\mathrm{NS}$ \\
\hline Communication Channels & 3.62 & 0.82 & 140 & 3.42 & 0.81 & 110 & 1.95 & NS \\
\hline Conflict Resolution & 4.19 & 0.84 & 140 & 4.36 & 0.61 & 110 & 1.76 & NS \\
\hline Citizenship Behavior & 3.97 & 0.81 & 140 & 3.80 & 1.27 & 110 & 1.27 & $\mathrm{NS}$ \\
\hline Past Satisfaction & 4.16 & 0.79 & 140 & 4.32 & 0.66 & 110 & 1.75 & $\mathrm{NS}$ \\
\hline $\begin{array}{l}\text { Customer contact by } \\
\text { phone/e-mail }\end{array}$ & 3.62 & 0.84 & 140 & 3.86 & 0.81 & 110 & $2.33^{*}$ & $\mathrm{~S}$ \\
\hline $\begin{array}{l}\text { Complaint/Grievance } \\
\text { Handling }\end{array}$ & 3.69 & 0.85 & 140 & 3.68 & 0.82 & 110 & 0.28 & $\mathrm{NS}$ \\
\hline Customer Care & 3.55 & 0.92 & 140 & 3.83 & 0.83 & 110 & $2.52^{*}$ & $\mathrm{~S}$ \\
\hline Responsiveness & 3.38 & 0.96 & 140 & 3.44 & 0.87 & 110 & 0.46 & $\mathrm{NS}$ \\
\hline Planning & 3.92 & 0.77 & 140 & 3.93 & 0.96 & 110 & 0.08 & $\mathrm{NS}$ \\
\hline $\begin{array}{l}\text { Improved retention and } \\
\text { better targeting of new } \\
\text { customers }\end{array}$ & 3.98 & 0.83 & 140 & 4.13 & 0.67 & 110 & 1.55 & $\mathrm{NS}$ \\
\hline Top Management Support & 3.83 & 0.79 & 140 & 3.84 & 1.300 & 110 & 0.08 & $\mathrm{NS}$ \\
\hline $\begin{array}{l}\text { Knowledge } \text { Management } \\
\text { Capabilities }\end{array}$ & 4.22 & 0.69 & 140 & 4.33 & 0.61 & 110 & 1.15 & $\mathrm{NS}$ \\
\hline Innovation and Quality & 3.95 & 0.75 & 140 & 4.35 & 0.59 & 110 & $4.63^{* * * *}$ & $\mathrm{~S}$ \\
\hline Technological Readiness & 3.80 & 0.82 & 140 & 3.96 & 1.009 & 110 & 1.46 & $\mathrm{NS}$ \\
\hline $\begin{array}{l}\text { Employee } \\
\text { feedback/attitudes towards } \\
\text { CRM }\end{array}$ & 3.47 & 0.86 & 140 & 3.46 & 0.86 & 110 & 0.11 & $\mathrm{NS}$ \\
\hline
\end{tabular}

\section{RESULTS \& DISCUSSION}

The results are presented in Table 1 and Table 2.

From Table 1 we can see that there is a significant difference between public and private sector bank managers for three of the CRM variables, namely customer contact by phone/e-mail, customer care, and innovation \& quality.

Table 2 shows that there are significant differences among the four groups of bank managers (public sector males, public sector females, private sector males, and private sector females) for eight variables (commitment, citizenship behavior, customer contact by phone/e-mail, planning, improved retention and better targeting of new customers, top management support, innovation \& quality, and technological readiness).

Table 1 shows that among 18 variables only three significantly differed, namely customer contact by phone/email, customer care, and innovation and quality. The first significant variable is customer contact by phone/e-mail , and this was found to be less intense in public sector banks $(\mathrm{M}=3.62)$ and more intense in private sector banks (M =3.86). This might be due to the fact that private sector banks are putting more effort into contacting customers by phone and e-mail to retain as many as possible. The second variable, customer care, is less intense in public sector 
banks $(M=3.55)$ and more intense in private sector banks $(M=3.83)$. This could be due to the fact that private sector banks actively respond to and interact with their customers more to resolve their problems.

Table 2. A summary of the ANOVA among the four groups of bank managers (public sector males, public sector females, private sector males, and private sector females) on the variables of customer relationship management (CRM) in Bihar.

\begin{tabular}{|c|c|c|c|c|c|c|}
\hline Name of Variable & Source of Variation & $\begin{array}{c}\text { Sum of Squares } \\
\text { (SS) }\end{array}$ & dff & $\begin{array}{c}\text { Mean Square } \\
\text { (MS) }\end{array}$ & $\bar{F}$ & $\begin{array}{c}\text { Level of } \\
\text { Significance }\end{array}$ \\
\hline \multirow[t]{3}{*}{ Adaptation } & Between Groups & 2.45 & 3 & 0.82 & \multirow[t]{3}{*}{1.05} & \multirow[t]{3}{*}{ NS } \\
\hline & Within Groups & 190.89 & 246 & 0.78 & & \\
\hline & Total & 193.34 & 249 & & & \\
\hline \multirow[t]{3}{*}{ Trust } & Between Groups & 1.45 & 3 & 0.48 & \multirow[t]{2}{*}{0.50} & \multirow[t]{2}{*}{ NS } \\
\hline & Within Groups & 239.48 & 246 & 0.97 & & \\
\hline & Total & 240.93 & 249 & & & \\
\hline \multirow[t]{3}{*}{ Commitment } & Between Groups & 4.38 & 3 & 1.46 & \multirow[t]{2}{*}{$3.89 * *$} & \multirow[t]{2}{*}{$\mathrm{S}$} \\
\hline & Within Groups & 92.45 & 246 & 0.38 & & \\
\hline & Total & 96.84 & 249 & & & \\
\hline \multirow[t]{3}{*}{ Communication Channels } & Between Groups & 2.99 & 3 & 0.100 & \multirow[t]{3}{*}{1.48} & \multirow[t]{3}{*}{ NS } \\
\hline & Within Groups & 165.08 & 246 & 0.67 & & \\
\hline & Total & 168.07 & 249 & & & \\
\hline \multirow[t]{3}{*}{ Conflict Resolution } & Between Groups & 2.34 & 3 & 0.78 & \multirow[t]{3}{*}{1.38} & \multirow[t]{3}{*}{ NS } \\
\hline & Within Groups & 138.67 & 246 & 0.56 & & \\
\hline & Total & 141.01 & 249 & & & \\
\hline \multirow[t]{3}{*}{ Citizenship Behavior } & Between Groups & 20.00 & 3 & 6.67 & \multirow[t]{3}{*}{$6.55^{* * * *}$} & \multirow[t]{3}{*}{$\mathrm{S}$} \\
\hline & Within Groups & 250.59 & 246 & 1.02 & & \\
\hline & Total & 270.59 & 249 & & & \\
\hline Past Satisfaction & Between Groups & 2.43 & 3 & 0.81 & 1.48 & NS \\
\hline & Within Groups & 134.90 & 246 & 0.55 & & \\
\hline & Total & 137.33 & 249 & & & \\
\hline Customer contact by & Between Groups & 5.43 & 3 & 1.81 & $2.68^{*}$ & $\mathrm{~S}$ \\
\hline phone/e-mail & Within Groups & 166.13 & 246 & 0.67 & & \\
\hline & Total & 171.56 & 249 & & & \\
\hline Complaint/Grievance & Between Groups & 0.74 & 3 & 0.25 & 0.35 & $\overline{\mathrm{NS}}$ \\
\hline Handling & Within Groups & 173.24 & 246 & 0.70 & & \\
\hline & Total & 173.97 & 249 & & & \\
\hline Customer Care & Between Groups & 5.56 & 3 & 1.85 & & \\
\hline & Within Groups & 187.11 & 246 & 0.76 & 2.44 & NS \\
\hline & Total & 192.67 & 249 & & & \\
\hline Responsiveness & Between Groups & 3.03 & 3 & 1.01 & 1.19 & NS \\
\hline & Within Groups & 208.53 & 246 & 0.85 & & \\
\hline & Total & 211.56 & 249 & & & \\
\hline Planning & Between Groups & 28.41 & 3 & 9.47 & 14.97 **** & $\mathrm{S}$ \\
\hline & Within Groups & 155.57 & 246 & 0.63 & & \\
\hline & Total & 183.98 & 249 & & & \\
\hline Improved retention and & Between Groups & 5.70 & 3 & 1.90 & $3.33^{* *}$ & $\mathrm{~S}$ \\
\hline better targeting of new & Within Groups & 140.45 & 246 & 0.57 & & \\
\hline customers & Total & 146.15 & 249 & & & \\
\hline Top Management Support & Between Groups & 82.57 & 3 & 27.52 & $35.99^{* * * *}$ & $\mathrm{~S}$ \\
\hline & Within Groups & 188.10 & 246 & 0.76 & & \\
\hline & Total & 270.68 & 249 & & & \\
\hline Knowledge $\quad$ Management & Between Groups & 1.54 & 3 & 0.51 & 1.25 & NS \\
\hline Capabilities & Within Groups & 101.16 & 246 & 0.41 & & \\
\hline & Total & 102.70 & 249 & & & \\
\hline Innovation and Quality & Between Groups & 10.75 & 3 & 3.58 & $7.60^{* * * *}$ & $\mathrm{~S}$ \\
\hline & Within Groups & 115.93 & 246 & 0.47 & & \\
\hline & Total & 126.69 & 249 & & & \\
\hline Technological Readiness & Between Groups & 15.21 & 3 & 5.07 & $6.56^{* * * *}$ & $\mathrm{~S}$ \\
\hline & Within Groups & 190.15 & 246 & 0.77 & & \\
\hline & Total & 205.36 & 249 & & & \\
\hline Employee feedback/attitudes & Between Groups & 2.35 & 3 & 0.78 & 1.06 & NS \\
\hline towards CRM & Within Groups & 180.81 & 246 & 0.73 & & \\
\hline & Total & 183.16 & 249 & & & \\
\hline
\end{tabular}

Note: $* \mathrm{P}<.05$, ** $\mathrm{P}<.01$, *** $\mathrm{P}<.001, \mathrm{~S}=$ Significant, $\mathrm{NS}=$ Not significant. 
Additionally, private banks are trying to fulfill customers' needs in a way that will satisfy customers' queries, provide them with a memorable experience, encourage them to come back, and motivate them to tell others about the bank's products and services. It is possible that private banks have better resources available to solve customers' problems and are shared to ensure that the issue is being addressed.

Customer service teams might have a better understanding of how to help customers, which can then be used to improve customer satisfaction. The third variable, innovation and quality, was found to be less intense in public sector banks $(\mathrm{M}=3.95)$ and more intense in private sector banks $(\mathrm{M}=4.35)$. It is true that, nowadays, private sector banks are taking more of an initiative than public banks to innovate and provide a good quality of services to customers in terms of service, better facilities, and new technology.

The four groups of bank managers showed a significant difference for the variable of commitment. Commitment involves a long-term desire to maintain a valued partnership, an authentic engagement, real value, and human connections (i.e., trust), which all add up to equal customer commitment. In terms of citizenship behavior, the four groups differed significantly. This shows that banks should support the social and psychological environments in which task performance takes place. Ultimately, the goal of CRM is to create effective and efficient working relationships, meet customer/citizen needs, and the needs of those who serve them. The third significant variable is customer contact by phone/e-mail. Banks should try to fulfill customer needs/demands in such a way that will resolve their queries, give customers a memorable experience, encourage repeat business, and motivate customers to spread the word about the bank's products and services. The fourth significant variable is planning. Sound CRM planning requires application development and delivery. It helps us to take a glimpse into the future and decide in advance the best way to deal with situations. Efficient planning bridges the gap between where we are and where we want to be. The fifth significant variable is the most common pitfall for businesses around the world, which is that they think that if they have a great product or service, then customer retention will follow naturally. This is true, and it is important for companies because the cost of acquiring new customers is far greater than the cost of maintaining relationships with current customers. The sixth significant variable is top management support. Senior managers are key stakeholders in any large organization, and senior management must remain fully engaged throughout any process as this implies that they are willing to take appropriate action to address issues raised by their teams, mitigate any project risks, and provide leadership, thus contributing to the success of projects. The time taken in the approval process should not be rushed. Without the full approval of top-level management, projects may not be successful if they take too long to implement. The seventh significant variable is innovation and quality, which help to manage customer relationships by ensuring that customers have a good understanding of processes/services, and by delivering good quality products and services based on added value for target customers. The eighth, and last, variable is technological readiness. The primary purpose of using technology readiness levels is to help management in making decisions concerning the development and transition of technology, which is needed to manage the progress of research and development activities within an organization.

\section{CONCLUSION}

From the above results, it can be seen that both public and private sector groups showed more similarities than differences, therefore, both of the hypotheses are partially accepted. The results show that private sector banks are sincere in adopting new CRM techniques, are seen as trustworthy by their customers, and communicate more effectively with customers. This study aims to provide a useful contribution to banking organizations. It may also help industries or practitioners to understand the importance of CRM to achieve customer satisfaction and customer retention. This study also provides some insightful learning to banking organizations, which have a direct link with the economic growth of a nation, and will assist them in formulating their CRM processes. 
Funding: This study received no specific financial support.

Competing Interests: The authors declare that they have no competing interests.

Acknowledgement: All authors contributed equally to the conception and design of the study.

\section{REFERENCES}

Adiele, K. C., \& Opara, B. C. (2014). Analysis of corporate identity on customer patronage of banks in Nigeria. International Review of Management and Business Research, 3(4), 1809-1818.

Bansal, I., \& Sharma, R. (2008). Indian banking services: Achievements and challenges. ICFAI Journal of Services Marketing, 6(2), $32-43$.

Berry, L. L. (1983). Relationship marketing in Berry, L.L, Shostac, G. Land Upha, G.D, emerging perspective in service marketing (pp. 25-28). Chicago: American Marketing Association.

Brown, S. A. (2000). Customer relationship management: A strategic imperative in the world of e-business. Canada: John Wiley \& Sons.

Dwyer, F. R., Schurr, P. H., \& Oh, S. (1987). Developing buyer-seller relationships. Journal of Marketing, 51(2), 11-27.

Girdhar, S. (2009). Building relationship through internal customer: A study of South Asian selected co-operative banks with special reference to Surat district of Gujarat State. Pranjana - The Journal of Management Wwareness, Delhi, 12(2), 32-45.

Hallowell, R. (1996). The relationships of customer satisfaction, customer loyalty, and profitability: An empirical study. International Journal of Service Industry Management, 7(4), 27-42.

Hussain, I., Hussain, M., Hussain, S., \& Sajid, M. (2009). Customer relationship management: Strategies and practices in selected banks of Pakistan. International Review of Business Research Papers, 5(6), 117-132.

Kotler, P., \& Keller, K. (2006). Marketing management (12th ed.). New Jersey: Pearson Prentice Hall.

Kumar, M., Ashok, \& Rajesh. (2009). Whether today's customers are satisfied? - A study with banks. Indian Journal of Marketing, $39(9), 45-53$.

Mylonakis, J. (2009). Bank satisfaction factors and loyalty: A survey of the Greek bank customers. Innovative Marketing, 5(1), 1625.

Pahuja, A., \& Verma, R. (2008). Customer relationship management: The need of the hour. Marketing Mastermind, 6(3), 67-73.

Panda, T. K. (2003). Creating customer lifetime value through effective CRM in Financial Services Industry. Journal of Services Research, 2(2), 157-171.

Parasuraman, A., Zeithaml, V. A., \& Berry, L. L. (1985). A conceptual model of service quality and its implications for future research. Journal of Marketing, 49(4), 41-50. Available at: https://doi.org/10.2307/1251430.

Payne, A. (2012). Handbook of CRM: Achieving excellence in customer management. Oxford: Butterworth-Heinemann.

Peppers, D., \& Rogers, M. (2004). Managing customer relationships: A strategic frame work (2nd ed.). Hoboken, New Jersey: John Wiley \& Sons, Inc.

Picton, D., \& Broderic, A. (2005). Integrated marketing communications (2nd ed.). Essex: Pearson Education Limited.

Puccinelli, B. (1999). Bank delivery, service channels require more personal attention in Bank Systems \&Technology. Bank Systems \& Technology, 36-48.

Rahimi, R., \& Kozak, M. (2017). Impact of customer relationship management on customer satisfaction: The case of a budget hotel chain. Journal of Travel \& Tourism Marketing, 34(1), 40-51. Available at: https://doi.org/10.1080/10548408.2015.1130108.

Ray, B. (2007). An analytical approach to understand customers from the perspective of profit making. Marketing Mastermind The Icfai University Press, 3(2), 52-55.

Rootman, C., Tait, M., \& Bosch, J. (2008). Variables influencing the customer relationship management of banks. Journal of Financial Services Marketing, 13(1), 52-62. Available at: https://doi.org/10.1057/fsm.2008.5.

Sachdev, S. B., \& Verma, H. V. (2004). Relative importance of service quality dimensions: A multisectoral study. Journal of Services Research, 4(1), 59-81.

Sherif, K. (2002). Assessing the introduction of electronic banking in Egypt using the technology acceptance model. Hershey, PA, USA: Idea Group Inc. 
Swift, R. (2001). Accelerating customer relationship using CRM and relationship technologies. New York: Prentice Hall Inc.

Tamilarasan, R. (2011). Customer relationship management in banking services. Advances in Management, 4(1), 27-29.

Wali, A. F., \& Opara, B. (2013). The impact of customer appreciation service on customer loyalty patronage: Evidence from Nigeria financial sector. European Journal of Business and Management, 5(1), 163-169.

Wang, Y., Lo, H. P., Chi, R., \& Yang, Y. (2004). An integrated framework for customer value and customer-relationshipmanagement performance: A customer-based perspective from China. Managing Service Quality: An International Journal, 14(2/3), 169-182.

Zeithmal, V., \& Bitner, M. (2003). Service marketing: Integrating customer focus across the firm. New York: McGraw-Hill.

Appendix A: Definitions of the variables on customer relationship management (CRM).

Adaptation: The acceptance of changes in processes, practices and use of CRM techniques in the banking
sector.
Trust: The belief that someone is good and honest and will not harm to anyone in the organization.
Commitment: A force that binds an individual to a course of action relevant to one or more targets. It is also
the relative strength of an individual's identification with and involvement in an organization.
Communication channel: A medium through which a sender transmits messages.
Conflict resolution: The clarification of what the disagreement is, establishing a common goal for both parties,
and discussing ways to meet the common goal, determine the barriers to the common goal, and agree on the
best way to resolve the conflict.

Citizenship behavior: This is conceptualized as synonymous with the concept of contextual performance defined as performance that supports the social and psychological environment in which task performance takes place.

Past satisfaction: This is defined as getting what you wanted or desired, or the payment of a past debt.

Customer contact by phone/e-mail: A process through which bank employees contact a customer about new policies, customer support, and business procedures via phone or e-mail.

Complaint/grievance handling: This is an expression of dissatisfaction made by the customers regarding the products or services of the concerned organization and how the organization is handling the grievances process itself to solve the customer's grievances amicably..

Customer care: Customer care is the act of responding to customer needs and expectations in a way that will give them a memorable experience, motivate them to come back, and compel customers to tell others about the company's products and services.

Responsiveness: Responsiveness in the context of a system can be defined as the outcome that can be achieved when institutions and institutional relationships are designed in such a way that they are cognizant and respond appropriately to the legitimate expectations of individuals.

Planning: Deciding in advance what to do, how to do it, and who is to do it. Planning bridges the gap between where we are and where we want to go.

Improved retention and better targeting of new customers: Programs focused on customer retention and better targeting of new customers can be powerful tool in the arsenal of CRM. It is important for most companies because the cost of acquiring a new customer is far greater than the cost of maintaining a relationship with a current customer.

Top management support: This refers to the highest-ranking authority that is responsible for the entire organization.

Knowledge management capabilities: Knowledge management is a conscious strategy of getting the right knowledge by the right people at the right time and helping people who transform information into action in ways that strive to improve organizational performance.

Innovation and quality: This is a process that results in a substantially changed object, and quality refers to the degree to which a set of inherent characteristics fulfils a set of requirements for employees as well as customers.

Technological readiness: This is a process that enables the assessment of the maturity of a particular technology and the consistent comparison of maturity between different types of technology in the context of a specific system, application and operational environment in the organization.

Employees' feedback/attitudes towards CRM: This is systematic process through which we measure the employees' performance and their attitudes towards work in the banking sector.

Views and opinions expressed in this article are the views and opinions of the author(s), International Journal of Management and Sustainability shall not be responsible or answerable for any loss, damage or liability, etc. caused in relation to/arising out of the use of the content. 